\title{
6. PALEOFLUIDS FROM THE MARGINAL RIDGE OF THE CÔTE D'IVOIRE-GHANA TRANSFORM MARGIN (HOLE 960A) AS THERMAL INDICATORS ${ }^{1}$
}

\author{
Marc Lespinasse $^{2}$, Jacques L. Leroy ${ }^{2}$, Jacques Pironon ${ }^{3}$, and Marie-Christine Boiron ${ }^{3}$
}

\begin{abstract}
Fluid inclusions linked to two quartz veins from the bottom of Hole 960A were studied using microthermometry and Raman microprobe analysis. Results suggest that circulation of hot fluid $\left(160^{\circ}-170^{\circ} \mathrm{C}\right)$ under low pressure $(10-20 \mathrm{MPa})$ occurred within the marginal ridge of the Ivory Coast-Ghana Transform Margin. The fluid composition varies with time, and is either seawater or a mixture of $\mathrm{H}_{2} \mathrm{O}-\mathrm{CH}_{4}-\mathrm{CO}_{2}$ fluids. Possible sources of heat for these fluids include circulation in friction zones linked to transform-fault dynamics, either at depth in a thinned continental crust or in the hot oceanic crust south of the sampled area. The passage of the Mid-Atlantic Ridge axis to the south of the sampled zone occurred later than the vein formation and therefore cannot be considered a heat source.
\end{abstract}

\section{INTRODUCTION}

The inclusions of fluids in minerals are witnesses of fluid circulation trapped during (primary inclusions) or after (secondary fluid inclusions) the crystallization of the host minerals. Their analysis allows reconstruction of the characteristics and the history of these presently inactive thermal systems. In the case of a marginal ridge adjacent to a margin transform fault, different heat sources are possible and have been proposed. These include sedimentary and/or tectonic burials and thermal flow induced by the friction along the fault. In the case of the Ivory Coast-Ghana Transform Margin, other sources might have existed, especially in relation to the presence and displacement of an oceanic lithosphere with a mid-oceanic ridge in contact with the sampled zone (Mascle and Blarez, 1987; Basile et al., 1993). The characteristics of the organic matter recovered during Ocean Drilling Program (ODP) Leg 159, the thermal maturation of the clay minerals in these sediments (Shipboard Scientific Party, 1996), and the alteration of the microfauna caused by the temperature increase at the bottom of Hole 960A (Masure et al., Chap. 24, this volume) also suggest the existence of such a thermal anomaly.

Fluid inclusion studies (microthermometric and Raman analyses) were therefore undertaken to determine the pressure-volume-temperature-composition (PVTX) characteristics of the fluids present in the marginal ridge and to retrace a part of the thermal history of the constituent sediments.

\section{SAMPLES}

Only two small quartz veins, sampled at the bottom of Hole 960A could be studied. The first vein, ODP1, is located 442.1 meters below seafloor (mbsf; Sample 159-960A-60R-1, 17-21 cm) and the second, ODP2, is located $446.6 \mathrm{mbsf}$ (Sample 159-960A-61R-1, 41-44 cm), in a silty sandstone attributed to the Albian (Fig. 1). Their orientations are unknown. Calcite veins from Holes 962B and 962D were not studied because the fluid inclusions were too small $(<5 \mu \mathrm{m})$.

${ }^{1}$ Mascle, J., Lohmann, G.P., and Moullade, M. (Eds.), 1998. Proc. ODP, Sci. Results, 159: College Station, TX (Ocean Drilling Program).

${ }^{2}$ Université Henri Poincaré Nancy 1, Laboratoire Etude des Systèmes Hydrothermaux, BP 239, 54506 Vandoeuvre-lès-Nancy cedex, France. lespinas @lpesh.u-nancy.fr

${ }^{3}$ CREGU and GDR CNRS-CREGU 077, BP 23, 54501 Vandoeuvre-lès-Nancy cedex, France.

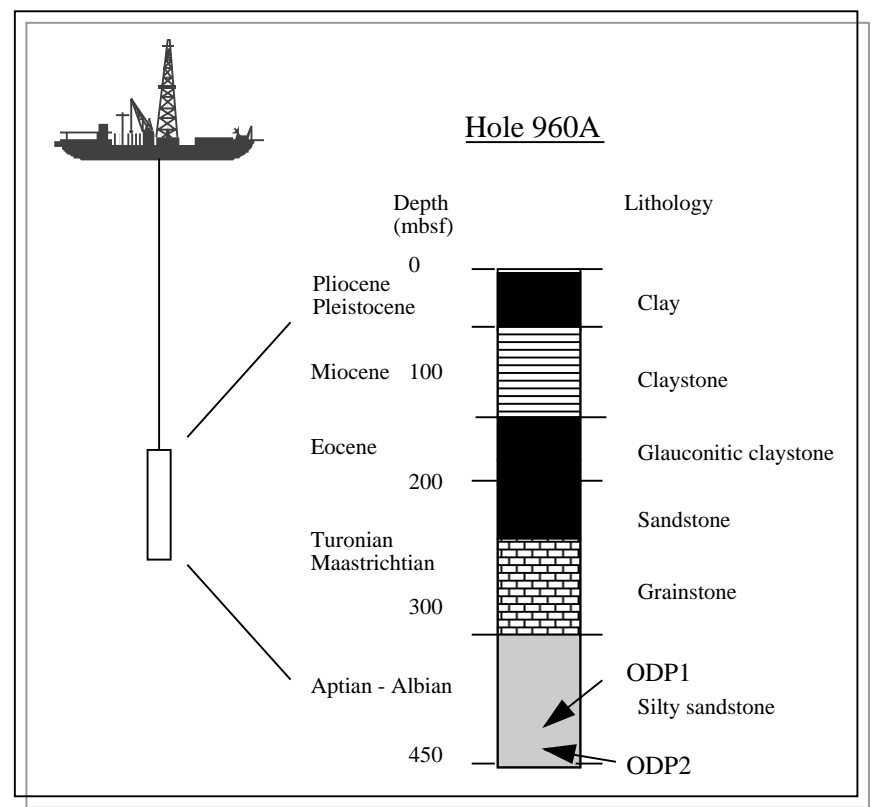

Figure 1. Simplified stratigraphic column of Hole 960A and locations of the samples ODP1 and ODP2.

The ODP1 vein, which is a subvertical milky quartz vein with microscopic crystals, was brecciated and cemented by secondary quartz. This corresponds to a rapid filling and brittle tectonic activity (syn- or post-filling). The vein borders are rectilinear. The ODP2 vein contains large crystals of an extremely limpid quartz, which indicates a slower crystallization rate. Borders are also rectilinear. The ODP2 sample is not syn- or post-deformed and brecciated. Because of the proximity of these two samples ( $4.5 \mathrm{~m}$ apart), one can conclude that the ODP1 vein was filled before the ODP2 vein.

\section{ANALYTICAL METHODS}

Microthermometric studies of fluid inclusions were performed on wafers $(<300 \mu \mathrm{m}$ in thickness) using a Chaixmeca heating-freezing stage (Poty et al., 1976). The stage was calibrated using melting- 
point standards at $\mathrm{T}>25^{\circ} \mathrm{C}$ and natural and synthetic fluid inclusions at $\mathrm{T}<0^{\circ} \mathrm{C}$. The rate of heating was monitored to get an accuracy of $\pm 0.2^{\circ} \mathrm{C}$ during freezing, $\pm 1^{\circ} \mathrm{C}$ when heating over the $25^{\circ}-400^{\circ} \mathrm{C}$ range, and $\pm 4^{\circ} \mathrm{C}$ over the $400^{\circ}-600^{\circ} \mathrm{C}$ range. Salinity, expressed as wt $\% \mathrm{NaCl}$ equivalents and fluid density of $\mathrm{H}_{2} \mathrm{O}$-salt inclusions were calculated from microthermometric data using equations from Bodnar (1993). In volatile-bearing fluid inclusions, $\mathrm{CO}_{2}$ was identified by melting a solid at $56.6^{\circ} \mathrm{C}$ (pure $\mathrm{CO}_{2}$ ) or below $56.6^{\circ} \mathrm{C}$ when mixed with other carbonaceous compounds. The volumetric fraction of the different phases observed in the inclusions at $20^{\circ} \mathrm{C}$ (aqueous liquid, aqueous vapors, or volatile-rich phase) were estimated by reference to the volumetric chart of Roedder (1984).

Molar fractions of $\mathrm{CO}_{2}, \mathrm{CH}_{4}, \mathrm{H}_{2} \mathrm{~S}$, and $\mathrm{N}_{2}$ were determined in individual fluid inclusions by micro-Raman analysis, performed on a DILOR X-Y multichannel modular Raman spectrometer at CREGU, Nancy, France. Bulk composition and molar volume were then computed from PVTX properties of individual inclusions in the C-O-H-S system (Dubessy et al., 1989; Thiery et al., 1994; Bakker et al., 1996). The P-T properties of aquo-carbonic inclusions are modeled for the system $\mathrm{H}_{2} \mathrm{O}-\mathrm{CO}_{2}-\mathrm{CH}_{4}$ using the $\mathrm{V}$-X data and the equation of Kerrick and Jacobs (1981) and Jacobs and Kerrick (1981), and for the $\mathrm{H}_{2} \mathrm{O}$ $\mathrm{NaCl}$ system data from Zhang and Frantz (1987).

\section{RESULTS \\ ODP1 Quartz Vein (Sample 159-960A-60R-1, 17-21 cm; 442.1 mbsf)}

Fifteen fluid inclusions have been studied in the largest quartz crystals. They are all two-phase (liquid and vapor) primary inclusions and are, therefore, contemporaneous with the vein filling. There is no evidence of decrepitation resulting from an internal increase in overpressure in relation to an increase in temperature after their formation. The fluid studied in this sample is purely aqueous. No traces of carbonaceous compounds such as $\mathrm{CO}_{2}$ or hydrocarbons have been observed. The fluid salinity is similar to the seawater salinity (3.4 \pm $0.2 \mathrm{wt} \%$ or $0.6 \pm 0.06 \mathrm{M} \mathrm{NaCl} \mathrm{eq)}$, as indicated by the melting temperature of the ice $\left(\mathrm{T}_{\mathrm{m}}=-2^{\circ} \pm 0.2^{\circ} \mathrm{C}\right)$. The homogeneity of the volumic ratios, $\left(\mathrm{V}_{\text {liquid } \mathrm{H}_{2} \mathrm{O}} / \mathrm{V}_{\text {inclusion }},(90 \%-95 \%)\right.$ observed in the inclusions at $20^{\circ} \mathrm{C}$ and a total homogenization to the liquid phase indicate that the fluid was a single phase liquid during its trapping. The homogenization temperatures of the two fluid phases $\left(\mathrm{T}_{\mathrm{h}}=+160^{\circ} \pm\right.$ $15^{\circ} \mathrm{C}$ ) are therefore minimal temperatures for trapping this fluid.

\section{ODP2 Quartz Vein (Sample 159-960A-61R-1, 41-44 cm; 446.6 mbsf)}

The second studied fluid inclusions (22) are primarily two-phase inclusions, such as those of the ODP1 quartz sample, but their contents are completely different. They all belong to the $\mathrm{H}_{2} \mathrm{O}-\mathrm{CH}_{4}-\mathrm{CO}_{2}$ system, with a dark phase (the carbonaceous phase) surrounded by a light one (liquid water) at room temperature. Two groups can be distinguished according to their microthermometric characteristics at low temperature (Table 1; Fig. 2): the density of the carbonaceous phase as indicated by its homogenization temperature either in the vapor (Group a) or in the liquid (Group b) fields, and its composition as indicated by the melting temperatures of the solid $\mathrm{CO}_{2}$ and of the clathrate. It is not possible to know whether these two groups were synchronous.

Only $\mathrm{CO}_{2}$ and $\mathrm{CH}_{4}$, with a low molar ratio $\mathrm{CO}_{2} / \mathrm{CH}_{4}(0.13-0.25)$ were detected and analyzed by micro-Raman analyses on six selected fluid inclusions. No hydrocarbons other than $\mathrm{CH}_{4}$ were observed. $\mathrm{N}_{2}$ is only present in the group a inclusions. The bulk composition of these inclusions was calculated using both the microthermometric and the Raman data (Table 1$)$. The salinity of the aqueous phase $(0.8$ $\mathrm{M}-2.1 \mathrm{M} \mathrm{NaCl})$ is one to three times higher than the seawater salinity.

For the two groups, the homogenization of the inclusions occurs in the temperature range between $345^{\circ}$ and $378^{\circ} \mathrm{C}$ and in the field of the carbonaceous mixture. However, the homogeneous fluid is a vapor for group A and a liquid for group B. Because of the presence of both vapor (group A) and liquid (group B) during trapping, and not completely constant volumic ratios $\left(\mathrm{V}_{\text {liquid } \mathrm{H}_{2} \mathrm{O}} / \mathrm{V}_{\text {inclusion }}=10 \%-20 \%\right.$ for group A and 10\%-40\% for group B), trapping of two-phase fluids (boiling) is possible. If correct, the lowest measured homogenization temperature $\left(345^{\circ} \mathrm{C}\right)$ is the trapping temperature of both fluids.

\section{DISCUSSION Origin of the Fluids}

The fluids contemporaneous with the filling of the ODP2 vein are a mixture of variable proportions of water saltier than seawater and carbonaceous compounds, $\mathrm{CH}_{4}$ and $\mathrm{CO}_{2}$. If these two carbonaceous products come from organic matter present in the sediments of the ridge, they are indicators of a mature fluid.

In the ODP1 quartz vein, the fluid is purely aqueous and similar to seawater. The lack of carbonaceous compounds involves the initial lack of organic matter in the surrounding sediments and a complete impermeability of the rocks between ODP1 and ODP2. In the dynamic context of a transform fault, the absence of fracture and of fluid circulation between two levels, separated by only $4.5 \mathrm{~m}$, is difficult to imagine.

Meanwhile, maturation and fluid trapping could occur at distinct places and times and/or under different temperatures. It is thus easier, given our current state of knowledge, to imagine maturation of organic matter at depth and the upwards circulation of the carbonaceous compounds in relation to the formation of a dense fracture network. The difference in the composition of the fluids related to ODP1 and ODP2 quartz crystallization suggests that the filling of these two veins is not synchronous, which was previously deduced from the quartz texture, and corresponds to two fluid circulation stages.

\section{T-P Characteristics of the Fluids}

If we suppose that the filling depth of the ODP1 quartz vein was similar to the sampling depth in the drill hole (seawater: $2000 \mathrm{~m}$ seawater thickness and sediments: $440 \mathrm{mbsf}$, with an average density of 1.7), the fluid temperature can be calculated according to the pressure regime (Fig. 3). This results in calculated temperatures of $175^{\circ} \mathrm{C}$ under a lithostatic pressure regime $\left(\mathrm{P}_{\text {fluid }}=\mathrm{P}_{\text {Solid }}=27.4 \mathrm{MPa}\right)$ and $172^{\circ} \mathrm{C}$ under a hydrostatic one $\left(\mathrm{P}_{\text {fluid }}=\mathrm{P}_{\text {Water }}=24.4 \mathrm{MPa}\right)$. However, sedimentological and structural reconstructions (Basile et al., 1993; Shipboard Scientific Party, 1996; Benkhelil et al., Chap. 10, this volume) strongly suggest a rather early filling of these veins, and a thinner cover of sediments under a shorter water column. The previously calculated temperatures are therefore maximal temperatures. We can thus infer a probable temperature of the fluid to be between $160^{\circ}$ and $175^{\circ} \mathrm{C}$ at the time and place of the ODP1 quartz crystallization. This crystallization also occurred under low pressure, between 10 (no fluid boiling) and 24.4 MPa.

Whatever the fluid pressure regime, a minimal temperature of $160^{\circ} \mathrm{C}$ at $442 \mathrm{mbsf}$ (ODP1) corresponds to a minimal thermal gradient of $350^{\circ} \mathrm{C} / \mathrm{km}$. This gradient will be higher with the probable lower water and sediment thickness. Such a gradient cannot be explained by a single burial. If we consider a thermal equilibrium between the fluids and the percolated rocks, such a gradient involves a thermal anomaly during the formation of this quartz vein. If there is no equilibrium, the trapped fluids correspond to hydrothermal hot fluid cir- 
Table 1. ODP2 quartz. Microthermometric characteristics and composition (molal fraction) of the only six fluid inclusions (FI) analyzed using microRaman spectrometry.

\begin{tabular}{|c|c|c|c|c|c|c|c|c|c|c|c|c|}
\hline \multirow[b]{2}{*}{ Number } & \multicolumn{4}{|c|}{ Microthermometry data } & \multicolumn{3}{|c|}{ Raman data } & \multicolumn{5}{|c|}{ Bulk composition } \\
\hline & $\mathrm{TmCO}_{2}$ & ThC & $\mathrm{TmCl}$ & Th & $\mathrm{ZCO}_{2}$ & $\mathrm{ZCH}_{4}$ & $\mathrm{ZN}_{2}$ & $\mathrm{XH}_{2} \mathrm{O}$ & $\mathrm{XCO}_{2}$ & $\mathrm{XCH}_{4}$ & $\mathrm{XN}_{2}$ & $\mathrm{XNaCl}$ \\
\hline 2 & -68.4 & $-50.9 \mathrm{~V}$ & 15.4 & $365 \mathrm{c}$ & 18.0 & 79.4 & 2.6 & 58.8 & 7.7 & 31.7 & 1.0 & 0.8 \\
\hline 3 & -68.6 & $-50.3 \mathrm{~V}$ & 15.4 & $370 \mathrm{c}$ & 15.0 & 84.1 & 0.8 & 57.7 & 6.5 & 34.5 & 0.4 & 1.0 \\
\hline 14 & -71.7 & $-68.0 \mathrm{~L}$ & 17.0 & $378 \mathrm{c}$ & 9.8 & 90.2 & 0.0 & 78.4 & 2.2 & 17.3 & 0.0 & 2.1 \\
\hline 16 & -71.6 & $-66.0 \mathrm{~L}$ & 18.2 & $350 \mathrm{c}$ & 14.0 & 86.0 & 0.0 & 28.5 & 10.0 & 60.7 & 0.0 & 0.8 \\
\hline 23 & -71.3 & $-62.9 \mathrm{~L}$ & 17.9 & - & 19.3 & 80.7 & 0.0 & 58.5 & 8.0 & 31.8 & 0.0 & 1.7 \\
\hline 13 & -71.9 & $-69.1 \mathrm{~L}$ & 17.1 & $375 \mathrm{c}$ & 11.8 & 88.2 & 0.0 & 49.7 & 6.2 & 44.2 & 0.0 & 1.4 \\
\hline
\end{tabular}

Notes: All temperatures in degrees Celsius. $\mathrm{TmCO}_{2}=$ melting temperature of solid $\mathrm{CO}_{2}$; ThC $=$ homogenization temperature of the carbonaceous phases in the vapor $(\mathrm{V})$ or in the liquid $(\mathrm{L})$ fields; $\mathrm{TmCl}=$ melting temperature of the clathrate; $\mathrm{Th}=$ homogenization temperature of the inclusion in the carbonaceous mixture $(\mathrm{c}) ;-=$ not determined. The error range is $\pm 0.01 \mathrm{M}$ for the $\mathrm{Z}$ values and $\pm 0.1 \mathrm{M}$ for the $\mathrm{X}$ values.

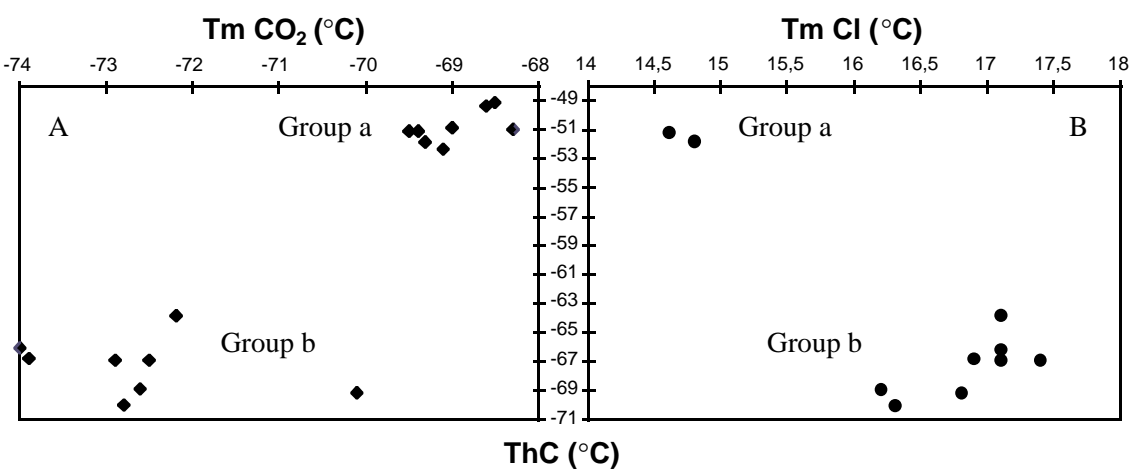

Figure 2. ODP2 microthermometric data in a homogenization temperature of the carbonaceous phases (Th C) vs. (A) melting temperature of the solid $\mathrm{CO}_{2}$ and vs. (B) the melting temperature of the clathrate $(\mathrm{Tm} \mathrm{Cl})$.

culations in a colder fractured area, which is the proposed mechanism.

We cannot determine the trapping temperatures of the fluids observed in sample $\mathrm{ODP} 2,345^{\circ} \mathrm{C}$ (boiling) or $>345^{\circ} \mathrm{C}$ (no boiling). The calculated isochores (Fig. 3) indicate fluids under low pressure, probably less than $10 \mathrm{MPa}$ for group A inclusions. Three P-T conditions can explain such a low pressure for the ODP2 quartz crystallization:

1. Between the ODP1 and ODP2 quartz crystallization, the sediments were partly eroded and/or the seawater height decreased. A probable emersion occurred during terminal Albian and early Cenomanian times (Mascle, Lohmann, Clift, et al., 1996).

2. The seawater and sediment thickness are similar for both ODP1 and ODP2 quartz crystallization. Thus, the ODP2 fluid was much hotter than the ODP1 fluid, over $300^{\circ} \mathrm{C}$.

3 . The pressure regime is hydrostatic, but the fluid column is not homogeneous and consists of both liquid (water) and vapor (carbonaceous compounds) phases. In such a case, the fluid pressure is less than the hydrostatic one.

Combinations of these conditions are, of course, possible.

\section{Heat Source for the Fluid Circulation: Role of the Transform Fault and/or of the Mid-Ocean Ridge}

If the burial of the sediments cannot be the heat source of the fluids, what is the role of the two other invoked heat sources: friction along the transform fault and the contribution of the oceanic lithosphere (oceanic crust and/or the passage of the mid-oceanic ridge)?

The first heat source is the creation of an oceanic crust, south of the transform fault. The heat maximum will correspond to the passage of the mid-oceanic ridge to the south of the Leg 159 area (Mascle and Blarez, 1987; Basile et al., 1993). Different parameters will control the efficiency of such a heat source: distance to the source (around 10-15 km), thermal conductivity of the materials, depth of the sediments, and heat exchange with seawater. However, whatever the contribution of the mid-oceanic ridge, it cannot be the heat source for the fluids, because the ODP1 and ODP2 vein filling occurs before the ridge passed to the south of the sampled area (Basile et al., 1993; Shipboard Scientific Party, 1996; Benkhelil et al., Chap. 10, this volume). On the other hand, the early existence of a hot oceanic lithosphere to the south of the marginal ridge can contribute to the thermal anomaly.

The second possible heat source is the friction along the transform fault. Few detailed studies have focused on this type of source. For Engel et al. (1986), transform faults have friction too weak to create a high thermal flow. Other studies demonstrated relationships between friction and creation of heat along the San Andreas fault (Lachenbruch and Sass, 1992). However, the in situ measurements of heat in the Cajon Pass drill hole indicate that the heat flow resulting from friction is less than the calculated flow. The heat contribution seems, therefore, strictly limited to the friction zone. However, even if this mechanism cannot create an important thermal anomaly in the surrounding rocks at significant distances, it can be sufficient to heat the fluids that circulate in the active transform fault.

Finally, as for many hydrothermal fluid circulations, we can also assume the presence of an underlying thermal flow, linked, for example, to the thinning of the continental crust (Mascle et al., 1995).

Bouillin et al. (in press), thanks to fission track studies on apatites and zircons, demonstrated that sandstones, sampled at the surface of the southern slope of the ridge during the Equanaute mission in 1992, were heated to between $120^{\circ}$ and $390^{\circ} \mathrm{C}$. Fluid inclusions of the ODP1 sample present no evidence of decrepitation (internal overpressure resulting from an increase of the temperature after their formation). Because fluid inclusions in quartz cannot support an overpressure $\left(\mathrm{P}_{\mathrm{d}}\right)$ greater than $85 \pm 5 \mathrm{MPa}$ (Leroy, 1979), the fluid inclusions here $\left(109.4 \mathrm{MPa}\left[\mathrm{P}_{\mathrm{d}}+\mathrm{P}_{\mathrm{F}}\right]\right)$ from the studied samples were not heated at a temperature greater than $245^{\circ} \pm 4^{\circ} \mathrm{C}$ after vein formation (Fig. 3). Even if the samples are not the same, it is possible to restrict 


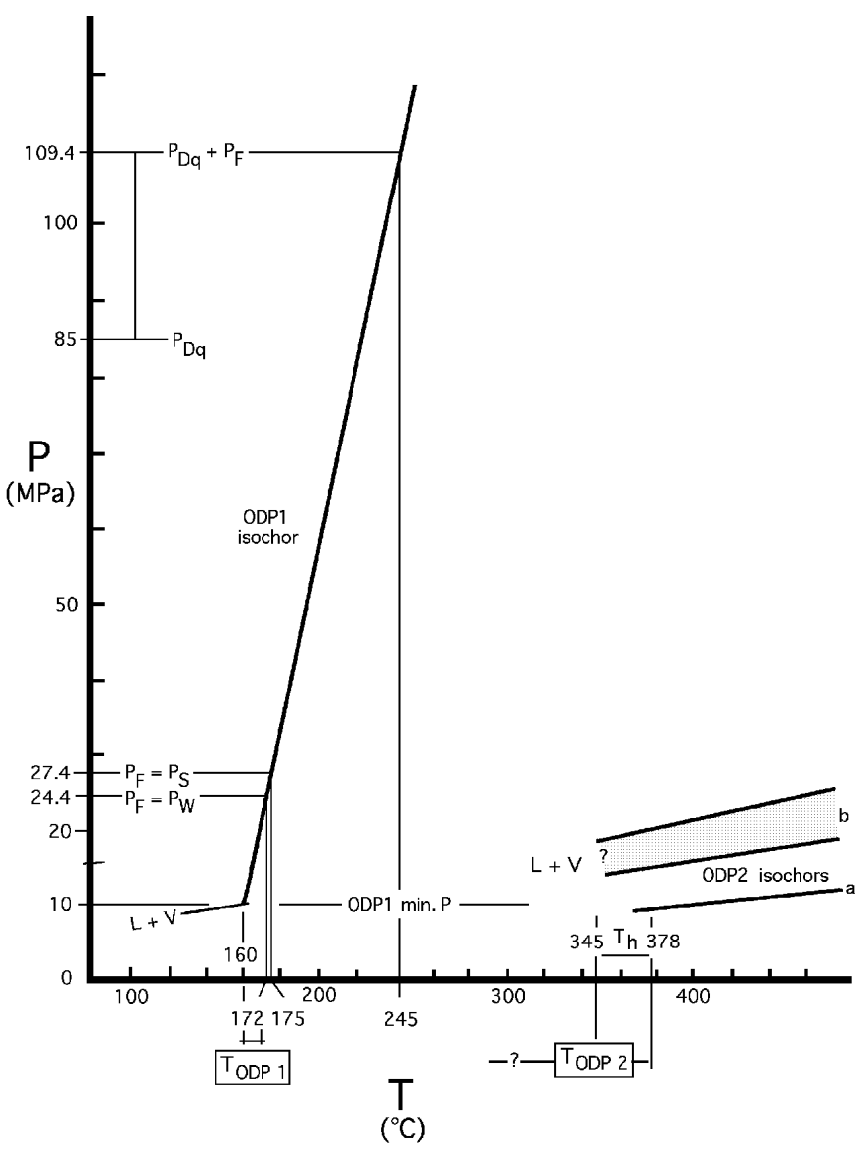

Figure 3. P-T diagram for the ODP1 and ODP2 fluids. $\mathrm{P}_{\mathrm{F}}=$ fluid pressure; $\mathrm{P}_{\mathrm{W}}=$ hydrostatic pressure $\mathrm{P}_{\mathrm{S}}=$ lithostatic pressure; $\mathrm{P}_{\mathrm{Dq}}=$ quartz decrepitation pressure; $\mathrm{Th}=$ homogenization temperature; $\mathrm{a}=$ Group $\mathrm{a} ; \mathrm{b}=$ Group $\mathrm{b}$.

the temperature interval of heating given by Bouillin et al. (in press) to $120^{\circ}-245^{\circ} \mathrm{C}$ instead of $120^{\circ}-390^{\circ} \mathrm{C}$. This temperature $\left(>245^{\circ} \mathrm{C}\right)$ also confirms the maturation of organic matter at depth (and not at the sample level) and the upward circulation of the carbonaceous compounds in relation to the formation of a dense fracture network.

\section{CONCLUSION}

The study of the fluid inclusions present in the quartz veins from the bottom of the Hole 960A indicates the following:

1. Hydrothermal circulations were linked to fracture permeability in the marginal ridge of the Ivory Coast-Ghana Transform Margin.

2. The fluids are aqueous and similar to seawater (ODP1). The presence of carbonaceous compounds $\left(\mathrm{CH}_{4}\right.$ and $\left.\mathrm{CO}_{2}\right)$ in the later ODP2 quartz, probably because of the maturation of organic matter in depth, implies changes in the geometry and in the composition of the fluid circulation with time. The two veins cannot be synchronous.

3 . The temperature of the ODP1 fluids, at the time and place of their trapping, ranged from $160^{\circ}$ to $175^{\circ} \mathrm{C}$. This does not predict the maximum temperature reached by these fluids at depth. $\mathrm{MPa}$.

4. The corresponding pressure was low, and ranged from 10 to 20

5. The sediments from Hole $960 \mathrm{~A}$ were not heated at a temperature over $245^{\circ} \mathrm{C}$ after the quartz vein filling.
6. The passage of the mid-oceanic ridge to the south of the Leg 159 area cannot be considered the heat source of these circulations because it postdated the quartz fillings.

7. The friction along the transform fault is a potential heat source for the fluids that circulate there. Continental crust thinning and creation of a hot oceanic crust towards the south can induce a higher thermal flow. They can also contribute to the heating of the fluids circulating at depth.

\section{REFERENCES}

Bakker, R.J., Dubessy, J., and Cathelineau, M., 1996. Improvements in the clathrate modeling: I. The $\mathrm{H}_{2} \mathrm{O}-\mathrm{CO}_{2}$ system with various salts. Geochim. Cosmochim. Acta, 60:1657-1681.

Basile, C., Mascle, J., Popoff, M., Bouillin, J.P., and Mascle, G., 1993. The Côte d'Ivoire-Ghana transform margin: a marginal ridge structure deduced from seismic data. Tectonophysics, 222:1-19.

Bodnar, R.J., 1993. Revised equation and table for determining the freezing point depression of $\mathrm{H}_{2} \mathrm{O}-\mathrm{NaCl}$ solutions. Geochim. Cosmochim. Acta, 57:683-684.

Bouillin, J.-P, Poupeau, G., Labrin, E., Basile, C., Sabil, N., Mascle, J., Mascle, G., Gillot, F., and Riou, L., in press. Fission track study of the marginal ridge of the Ivory Coast-Ghana transform margin. Geo-Mar. Lett.

Dubessy, J., Poty, B., and Ramboz, C., 1989. Advances in C-O-H-N-S fluid geochemistry based on micro-Raman spectrometric analysis of fluid inclusions. Eur. J. Mineral., 1:517-534.

Engel, J.F., Wiens, D.A., and Stein, S., 1986. Mechanisms and depths of Atlantic transform earthquakes. J. Geophys. Res., 91:548-577.

Jacobs, G.K., and Kerrick, D.M., 1981. Methane: an equation of state with application to the ternary system $\mathrm{H}_{2} \mathrm{O}-\mathrm{CO}_{2}-\mathrm{CH}_{4}$ system. Geochim. Cosmochim. Acta, 45:607-614.

Kerrick, D.M., and Jacobs, G.K., 1981. A remodified Redlich-Kwong equation for $\mathrm{H} 2 \mathrm{O}-\mathrm{CO} 2$ and $\mathrm{H} 2 \mathrm{O}-\mathrm{CO} 2-\mathrm{NaCl}$ mixtures at elevated pressures and temperatures. Am. J. Sci., 281:735-767.

Lachenbruch, A.H., and Sass, J.H., 1992. Heat flow from Cajon Pass, fault strength, and tectonic implication. J. Geophys. Res., 97:4995-5015.

Leroy, J., 1979. Contribution à l'étalonnage de la pression interne des inclusions lors de leur décrépitation. Bull. Mineral., 5 6:584-593.

Mascle, J., Basile, C., Pontoise, B., and Sage, F., 1995. The Côte d'IvoireGhana transform margin: an example of an ocean-continent transform boundary. In Banda, E., Talwani, M., and Thorne, M. (Eds.), Rifted Ocean-Continent Boundaries, NATO ASI Ser.: Dordrecht (Kluwer), 327- 339 .

Mascle, J., and Blarez, E., 1987. Evidence for transform margin evolution from the Côte d'Ivoire-Ghana continental margin. Nature, 326:378-381.

Mascle, J., Lohmann, G.P., Clift, P.D., et al., 1996. Proc. ODP, Init. Repts., 159: College Station, TX (Ocean Drilling Program).

Poty, B., Leroy, J., and Jachimowicz, L., 1976. Un nouvel appareil pour la mesure des temperatures sous le microscope, l'installation de microthermométrie Chaix - Meca. Bull. Soc. Fr. Mineral. Cristallogr., 99:182-186.

Roedder, E., 1984. Fluid inclusions. Rev. Mineral., Mineral. Soc. Am., 12.

Shipboard Scientific Party, 1996. Principal results. In Mascle, J., Lohmann, G.P., Clift, P.D., et al., Proc. ODP, Init. Repts., 159: College Station, TX (Ocean Drilling Program), 297-314.

Thiery, R., Vidal, J., and Dubessy, J., 1994. Phase equilibria modeling applied to fluid inclusions liquid-vapour equilibria and calculation to the study of molar volume in the $\mathrm{CO}_{2}-\mathrm{CH}_{4}-\mathrm{N}_{2}$ system. Geochim. Cosmochim. Acta, 58:1073-1082.

Zhang, Y., and Frantz, J.D., 1987. Determination of the homogenization temperatures and densities of supercritical fluids in the system $\mathrm{NaCl}-\mathrm{KCl}-$ $\mathrm{CaCl}_{2}-\mathrm{H}_{2} \mathrm{O}$ using synthetic fluid inclusions. Chem. Geol., 64:335-350.

Date of initial receipt: 16 September 1996

Date of acceptance: 24 February 1997 Ms 159SR-043 